\title{
Flying Fox: The Animal Origin of SARS-CoV Tianxi Sun*
}

Professorial Senior Engineer, Environmental Protection Bureau, Suzhou 215002, China.

\section{Abstract}

David Cyranoski (1 December, 2017) ${ }^{1}$ reported in Nature (news) that "Bat cave solves mystery of deadly SARS virus - and suggests new outbreak could occur", based on a paper (30 November, 2017) ${ }^{2}$ of some Chinese scientists in PLoS Pathogens. However, I don't agree with their conclusion that Yunnan bat is the culprit of SARS-CoV duo to their many doubtful points, logic errors and disregarding some existing evidences.

The animal origin of SARS-CoV is a cosmopolitan difficult question. Its solution must meet all suspicion, evidences and logic simultaneously. A wrong scientific conclusion can lead to terrible behavior, for example, leading the masked palm civets (Paguma larvata) to be massacred during 2002-2003 in China, as the culprit of SARS.

For this reason, I make important comments and clarifications on their above conclusions and provide an alternative way of thinking for the academic community to discuss.

Here I show: (1) the animal origin of SARS-CoV might be a flying fox, whose crucial genes of SARS virus - for a protein that allows the virus to latch onto and infect cells - had been activated by an underground uranium mine in the Panxi Rift $1,000 \mathrm{~km}$ away from Guangdong; (2) unless so complex process above is repeated, another SARS-CoV event will not erupt again within Guangdong; (3) SARS was a much extremely accidental event. Finally, I restore the entire process of SARSCoV event, using all the evidence chain and whole logic, from the point of view of system theory, based on the correlation between biology and geology. That might provide an impetus to similar investigation elsewhere.

Keywords: SARS; Flying Fox; Crucial Genes of SARS Virus; Activated; Evidence Chain; System Theory.

\section{*Corresponding author: Tianxi Sun \\ 18913505350@163.com}

Professorial senior engineer, Environmental Protection Bureau, Suzhou 215002, China.

Citation: Sun T (2018)Flying Fox: The Animal Origin of SARS-CoV. J Clin Epigenet. Vol.4 No.1:5

Received: February 06, 2018; Accepted: February 20, 2018; Published: February 24, 2018

\section{Introduction}

A French biologist once joked that the riddle of the SARS virus would be the most likely award for the Nobel price in medicine. David Cyranoski (December 2017) [1] reported in Nature news that "Bat cave solves mystery of deadly SARS virus - and suggests new outbreak could occur", based on a paper [2] of some Chinese scientists.

"In a remote cave in Yunnan province, virologists have identified a single population of horseshoe bats that harbours virus strains with all the genetic building blocks of the one that jumped to humans in 2002, killing almost 800 people around the world ... They warn that the ingredients are in place for a similar disease to emerge again," says David Cyranoski. However, I don't agree with the above conclusions of these Chinese scientists duo to their many doubtful points, logic errors and disregarding some existing evidences.

\section{Results}

\section{Many doubtful points}

1. Why didn't these horseshoe bats (Figure $\mathbf{1})^{1}$ firstly infect the villagers of only 1 kilometers from their holes? 
2. It is impossible for Yunnan bats to fly straight to Guangdong for 1,000 kilometers (Figure 2).

3. Since "no single bat had the exact strain of SARS coronavirus that is found in humans", so why did these Chinese scientists come to the conclusion that the bats are the culprit of the SARS event in 2002?

4. Why didn't the SARS event again erupt after 2002 2003?

\section{Logic errors}

(1) This group of bats is still alive, why SARS event has since disappeared?

(2) The village near the bat cave was not infected, and there wasn't any infection along all the way from Yunnan to Guangdong, why was only Guangdong infected?

(3) Many wild animals in Guangdong have been carrying SARS virus, such as the masked palm civet, but why have they never touched off an outbreak of SARS before 2002 and after 2003?

\section{Disregarded existing evidences}

(1) Mr. Wang whose first name isn't known to date, suddenly developed a strange disease. He was sent to the First People's Hospital of Foshan City (Figure 3) on November 16, 2002. Because of his critical condition and the hospital's helpless, he became the first victim died of SARS in the world. He had been a worker, but unemployed in April 2001. After that, he made a living by catching wild animals until he died [3].

(2) Although the SARS death case firstly appeared in Foshan City, it didn't cause infection there.

(3) The earliest SARS infection occurred in Shenzhen City, Guangdong Province. The first known infected person

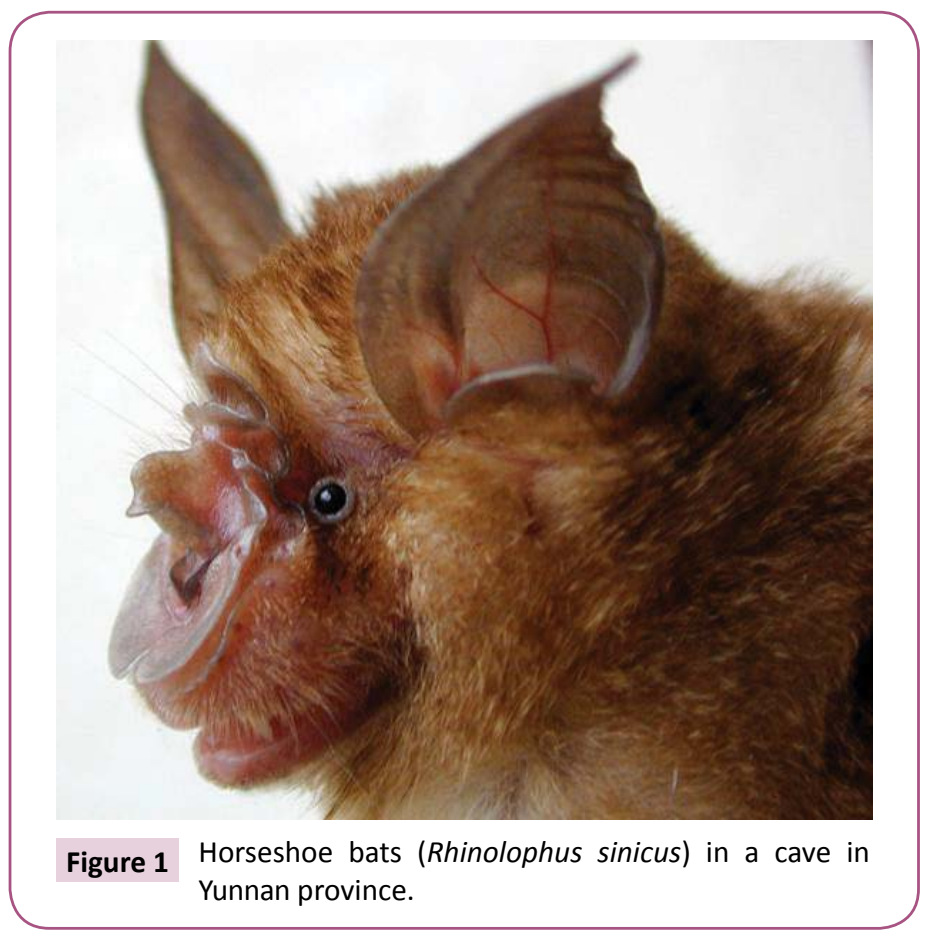

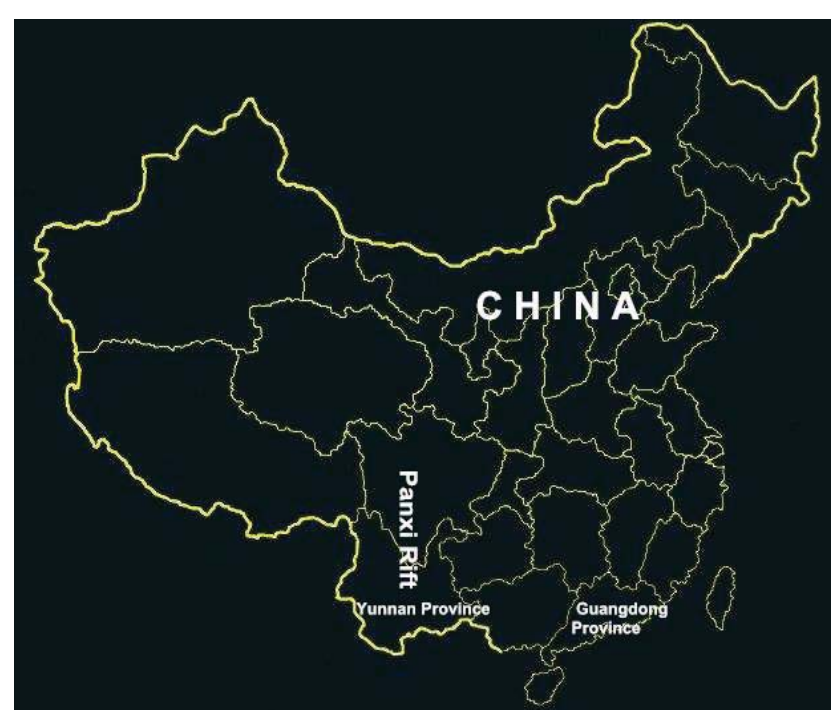

Figure 2 The distance between Yunnan and Guangdong (By Tianxi Sun).

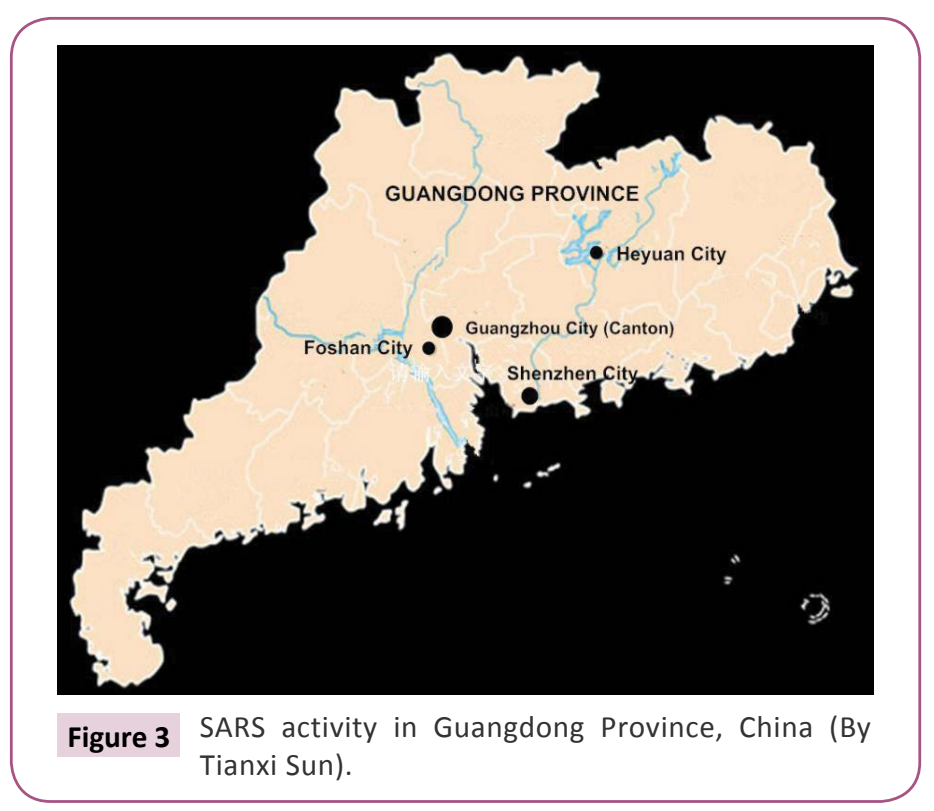

with SARS was Mr. Huang Xingchu, a wildlife restaurant chef in Shenzhen City. On December 5, 2002, Mr. Huang Xingchu was looked awful at Shenzhen. Three days later, he returned to his home in Heyuan City to recuperate. Because of his aggravation, on December 15, he was sent to the Heyuan People's Hospital for treatment. Nine medical personnel were infected in succession, thus suspecting Mr. Huang Xingchu was contagious. On December 17, 2002, he had trouble breathing and was an emergency referral to a millitary hospital in Guangzhou City (Canton) about 160 kilometers away from Heyuan City. On January 10, 2003, Mr. Huang recovered and discharged from the hospital and was identified as the first SARS report case in China.

(4) The Horseshoe bat's range of activities is so small that it's impossible to fly 1,000 kilometers to Guangdong. 
(5) There was a village only 1 kilometer from the Horseshoe bat cave, but the village wasn't infected.

(6) Many wild animals in Guangdong have been carrying SARS virus, but their crucial genes of SARS virus - for a protein that allows the virus to latch onto and infect cells - were not activated.

(7) Yunnan Province is located in Panxi Rift (Figure 4) [4], which has a lot of underground uranium deposits (Figure 5) [5].

(8) Nuclear emission can cause cell mutation and chromosome recombination.

(9) Rift valley has mechanisms to stimulate gene mutation [6].
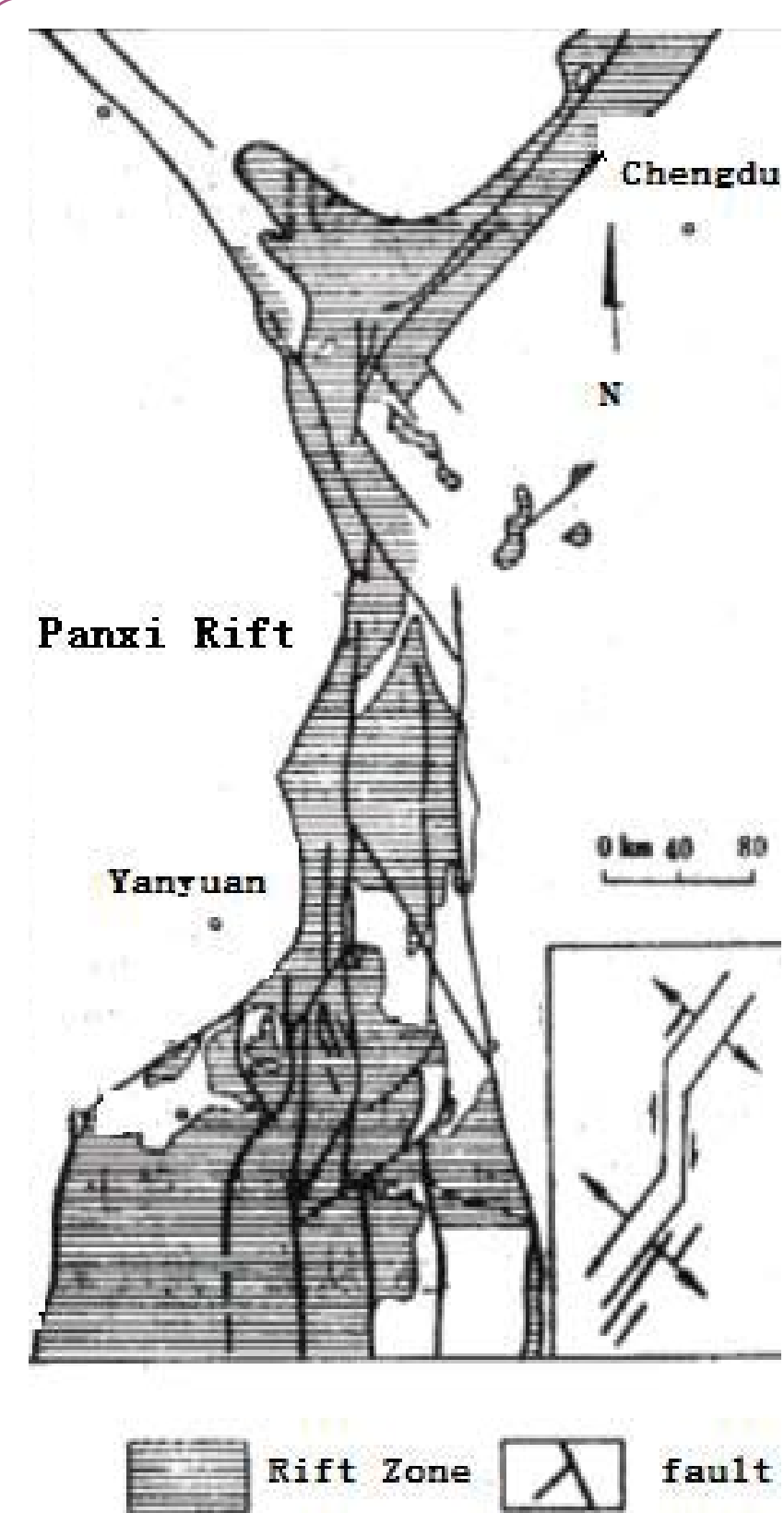

Rift Zone

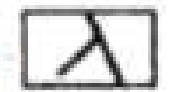

fault

Figure 4 Panxi Rift Zone, China.

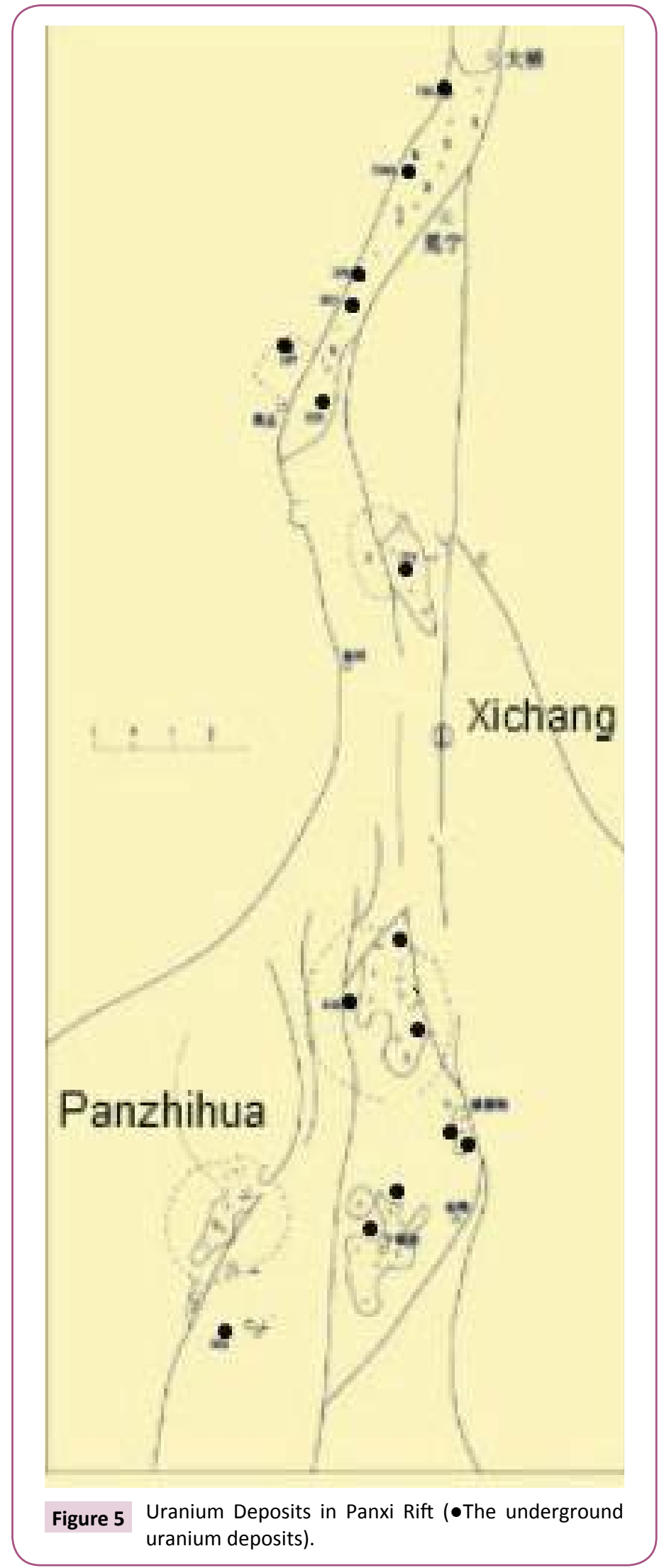

(10) The East African Rift Valley aroused AIDS virus, (Zaire and Uganda) [7], West Nile Virus (Egypt) [8], Rift Fever (Kenya) [9] , Ebola Bleeding Fever (Zaire) [10]. 
(11) The flying fox (Figure 6) [11] has a great range of activities and it has an ability to fly long distances, such as from Panxi Rift flying straight to Guangdong.

(12) The flying fox has a precedent for carrying a virus similar to SARS-CoV, for example, Ebola virus in Central Africa in1976 and 1995 [12].

\section{Why can't we think about it this way}

Now, I am try to restore the entire process of the SARS event, using all the evidence chain and whole logic, from the point of view of system theory, based on the correlation between biology and geology:

A big flying fox carrying SARS virus strayed into an underground uranium mine in Panxi Rift, whose crucial genes of SARS virus for a protein that allows the virus to latch onto and infect cells - were activated during the period in there.

Then, the flying fox got away from the underground uranium mine and flew straight to Heyuan mountainous area, Guangdong Province, over 1,000 kilometers.

In a cave of Heyuan, it was caught by Mr. Wang who made a living by catching wild animals, and then was sold to a wild animal restaurant in Shenzhen City where with developed economy.

Mr.Wang might have been hurt by this flying fox, and his life was

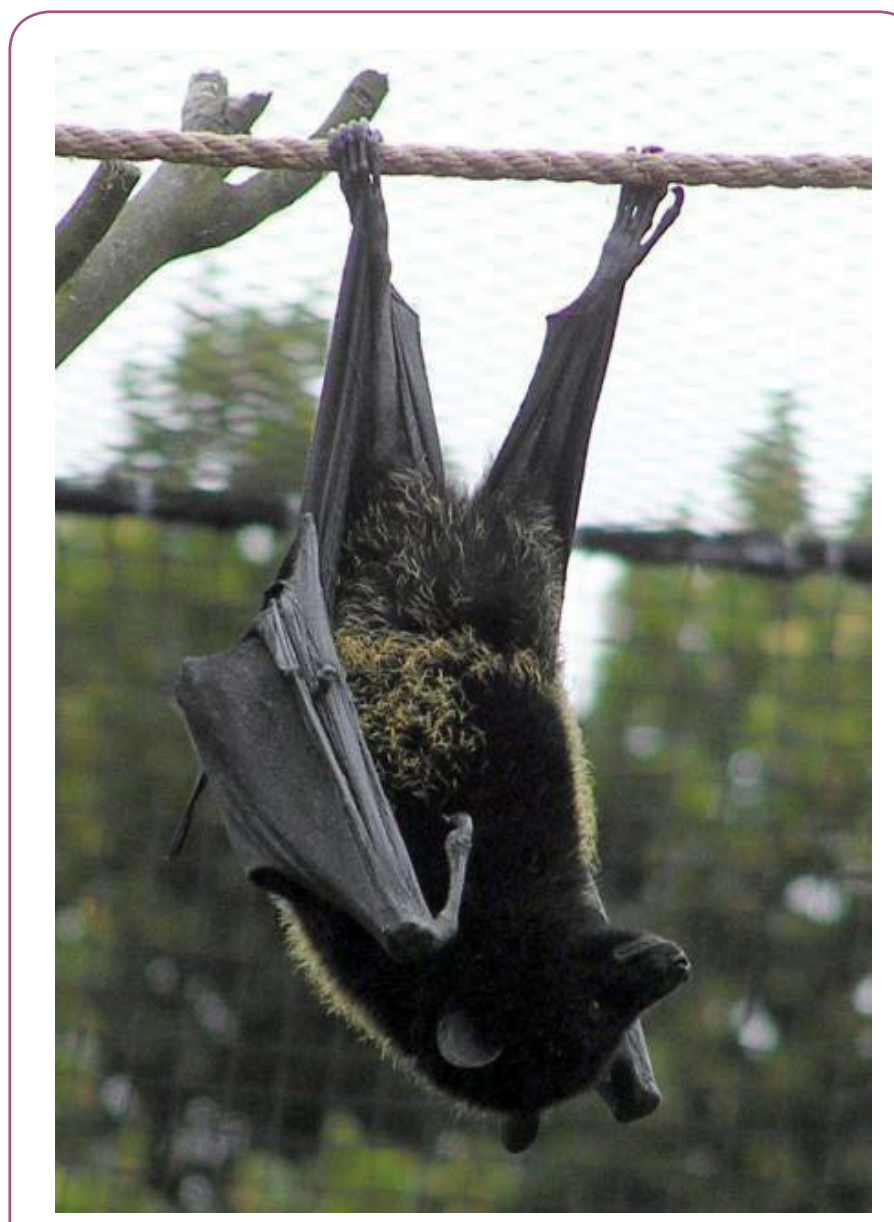

Figure 6 The flying fox (Pteropus). dying. On November 16, 2002, he was sent to the First People's Hospital of Foshan City about 180 kilometers away from Heyuan City. Foshan City's medical conditions were better. Because of his critical condition and the hospital's helpless, he became the first victim died of SARS in the world.

Not long afterward, on December 5, 2002, Mr. Huang Xingchu who probably had processed and cooked this flying fox in a Shenzhen wild animal restaurant, was looked awful at Shenzhen. Three days later, he returned to his home in Heyuan City to recuperate. Because of his aggravation, on December 15, he was sent to the Heyuan People's Hospital for treatment. Nine medical personnel were infected in succession, thus suspecting $\mathrm{Mr}$. Huang Xingchu was contagious. On December 17, 2002, he had trouble breathing and was an emergency referral to a millitary hospital in Guangzhou City (Canton) about 160 kilometers away from Heyuan City. On January 10, 2003, Mr. Huang recovered and discharged from the hospital and was identified as the first known infected person with SARS and the first SARS report case in China [13].

After that, the epidemic was outbroken and affected 39 countries, killing 908 people around the world [14].

In middle 2003, the SARS suddenly disappeared, because of human resistance and SARS virus' failure.

\section{Conclusions}

(1) These Chinese scientists were wrong about the conclusion of the outbreak of SARS in Guangdong, China in 2002. The culprit is not the Horseshoe bats, but might be the flying fox.

(2) These Chinese scientists ignored the evidence chain and went against the logic. So, their conclusion must be corrected.

(3) A wrong scientific conclusion can lead to terrible behavior, for example, leading the masked palm civets (Paguma larvata) to be massacred during 2002 2003 in China, as the culprit of SARS.

(4) The line of thinking for locking the suspect: Because there is no continental rift valley in Guangdong Province, China, so none of the native wildlife carrying the SARS virus in Guangdong has the geological conditions to activated its crucial genes in situ, and becoming a cuiprit of the SARS incident. Therefore, only the flying fox, which could be activated its crucial genes in the Panxi Rift in China, who had a similar "criminal" record in Africa, and whose ability could fly long distances such as from Panxi Rift flying straight to Guangdong, will become the only suspect.

(5) Consequently, there is a strong possibility that the SARS malignant event during 2002 2003 was caused by a big flying fox which carried SARS virus, who had strayed into an underground uranium mine in Panxi Rift, whose crucial genes of SARS virus - for a protein that allows the virus to latch onto and infect cells - had been activated there. The SARS event might be an extremely rare accident. Duo to the complex conditions of such the accident, SARS 
event should be almost impossible to explode again in Guangdong in future, which diametrically opposed to these Chinese scientists' conclusion that "the ingredients are in place for a similar disease to emerge again"

(6) My paper is across the breadth of biology, geology, and logic as well as criminology, thus constituting a system. It's a new method for solving scientific difficult problems,

\section{References}

1 David Cyranoski (2017) Bat cave solves mystery of deadly SARS virus - and suggests new outbreak could occur. Nature 552: 15-16.

2 Hu B, Zeng LP, Yang XL, Ge XY, Zhang W, et al. (2017) Discovery of a rich gene pool of bat SARS-related coronaviruses provides new insights into the origin of SARS coronavirus. PLoS Pathog 13: e1006698.

3 http://news.sina.com.cn/c/2013-02-25/093626351141.shtml

4 Sun, Tianxi (2004) Rift Evolutionism. (Chengdu : Sichuan Science \& Technology Press). ISBN: 7-5364-5411-2.

5 Luo L, Liu ZA (2011) Alkalic rocks and its correlation with u-mineralization and prospective on the axis position of Panzhihua Xichang rift. Progress Report on China Nuclear Science \& Technology.

6 Tianxi S (2015) Mechanisms of rift evolution. Science \& Mars Journal. using all the evidence chain and whole logic, from the point of view of system theory, based on the correlation between biology and geology. That might provide an impetus to similar investigation elsewhere.

\section{Declaration of Interests}

The author declares no competing interests.

7 Shi Y (1986) Aids: Acquired immune deficiency syndrome (in Chinese) Encyclopedic Knowledge 12: 60.

8 Tan XM (2002) West Nile virus spreads across United States, pp: 5.

9 Anon (2000) Rift heat sweeps across Yemen, French News Agency.

10 Anon (2003) Ebola brush past, Discover, June 2003.

11 https://en.wikipedia.org/wiki/Pteropus\#/media/File:Bristol.zoo. livfruitbat.arp.jpg

12 Resource \& Environmental Science Information Center of the Chinese Academy of Sciences. (2003). SARS Press Reports (In Chinese).

13 https://baike.baidu.com/item/SARS\%E4\%BA\%8B\%E4\%BB\%B6/7702 261 fr $=$ aladdin

14 Zhong N (2005) The animal origin of SARS-CoV. Acta Laboratorium Animalis Scientia Sinica S1: 5-6. 